\title{
BUTTERFLIES OF THE PEACE RIVER REGION OF ALBERTA AND BRITISH COLUMBIA
}

NORBERT G. KONDLA, British Columbia Forest Service, Box 672, McBride, British Columbia, V0J 6E0, EDWARD M. PIKE, Department of Biological Sciences, University of Calgary, Calgary, Alberta, T2N 1N4, and FELIX A. H. SPERLING, Department of Biology, University of Ottawa, Ottawa, Ontario. K1N $6 \mathrm{~N} 5$

Introduction Although the Peace River valley and surrounding area were explored early in Alberta's history and have been settled since the early 1900s, little has been published regarding its insect fauna. ${ }^{13,20}$ Works describing various aspects of the natural history of the Peace River valley include Spalding with a general synthesis, Moss on plants, and Soper on mammals and birds. ${ }^{25,26,36,37,38}$

With respect to butterflies, LlewelIyn-Jones lists 12 species from the Peace River district of British Columbia, and Bowman mentions six species from the Peace River district of Alberta. $^{1,21}$ Case and Bird discuss the Peace River valley as part of a larger study area and list 32 species collected along the Peace River valley of Alberta. ${ }^{3}$ Ferris reports distribution records for various Colias species in the study area., $8,10,11$ Other miscellaneous butterfly records have been reported in the News of the Lepidopterists' Society. ${ }^{31,32,33,34,35,41,42,43,44}$

Pike conducted extensive surveys while resident in Fairview from 1979 to 1986 and was the first to find many of the interesting butterfly taxa resident in this area. Sperling explored the region while conducting research on the genus Papilio from 1980 to 1986 . Kondla conducted extensive surveys over eight years from 1979 to 1992. We also include records provided by K. Avery, C. Schmidt, C. Guppy, G.J. Hilchie, J. Pelham, A.W. Rupp and J. Shepard. The primary purpose of this paper is to report on the results of this increased activity since 1979.

The study area we deal with herein consists of the Peace River valley from Bullhead Mountain/ Dunlevy area west of Hudson Hope, British Columbia, to Fort Vermilion, Alberta; low elevation streams tributary to the Peace River; nearby areas which historically contained aspen parkland and grasslands; ${ }^{25,26}$ most lands within $30 \mathrm{~km}$ of the Peace River; and a few other areas of low elevation poplar forest. Not included are Butler Ridge, British Columbia; and Mount Watt and Caribou Mountains in Alberta even though they are very close to the Peace River valley. They 


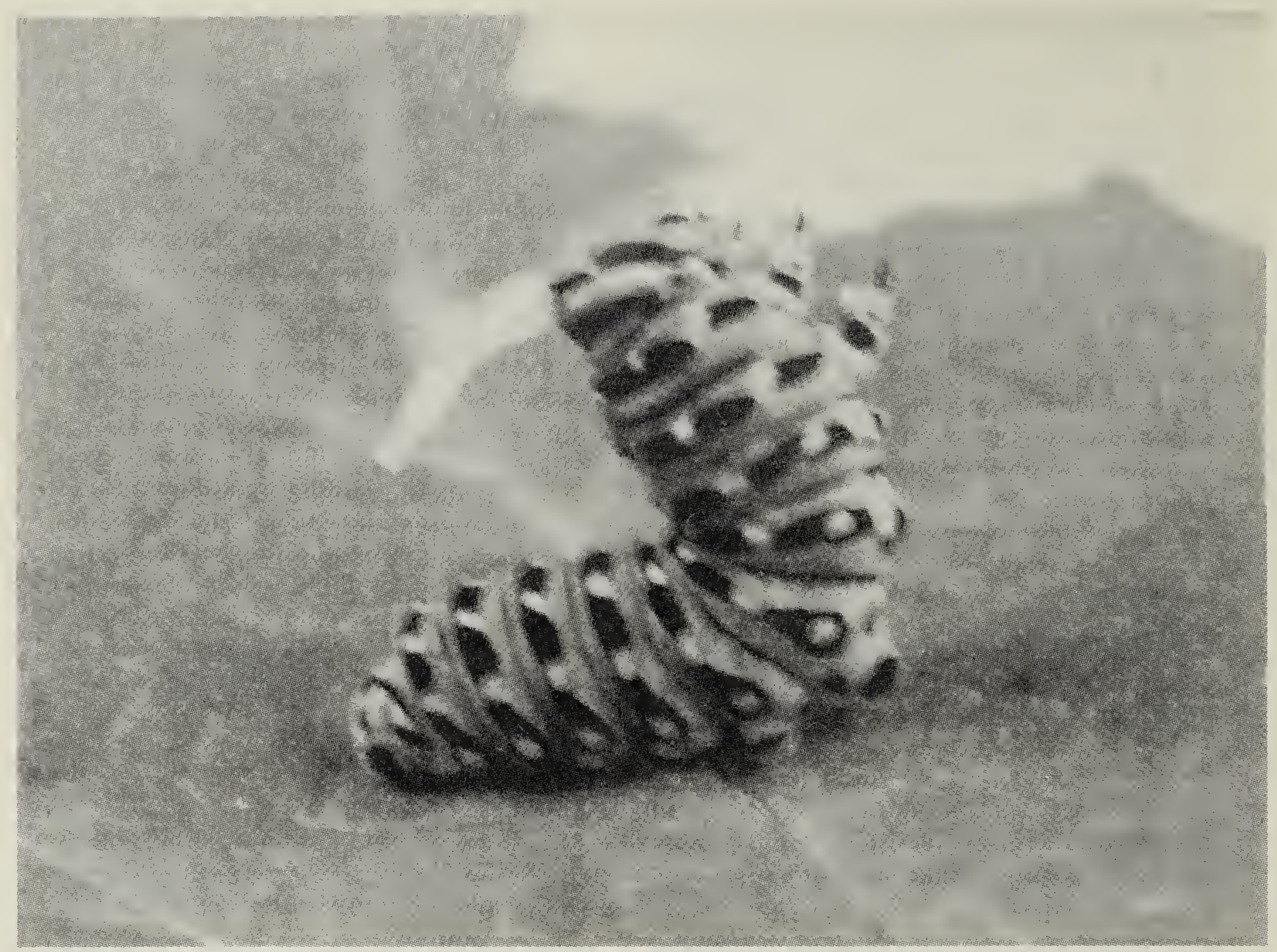

Fifth instar (Papilio Zelicaon) from Dixonville, Alberta.

Felix Sperling

are excluded because they support distinctly different habitats and fauna in comparison with the remainder of the study area.

Specific study sites are listed in Table 1 and geographically displayed in Figure 1. Over 96 sites were visited and more than 6400 specimens were collected and identified in the course of researching this region since 1979. Specimens of rare or doubtful taxa collected before 1979 have been examined and identifications checked. Specimens are in the personal collections of the authors, with some voucher specimens deposited in the Strickland Museum, Department of Entomology, at the University of Alberta, Edmonton.

Butterfly nomenclature has been both fluid and controversial in recent years. Consequently there is no sin- gle source that represents the consensus of butterfly students. Zoological names at the genus level follow Scott and we have taken species and subspecies names from a variety of published and unpublished contemporary sources. ${ }^{29}$ Our use of common names is reasonably consistent with Miller. ${ }^{23}$

\section{Annotated List}

\section{Hesperiidae}

Northern Cloudy Wing Thorybes pylades Scudder

LOCALITIES: 1c, 1e, 1f, 2a, 3h, 4b, 4j, 5d, 5i, 5j, 6g, 7b, 7i, 8d, 8e, 8i, 8j

Flight dates: 18 May to 12 July

Dreamy Dusky Wing Erynnis icelus (Scudder and Burgess)

LOCALITIES: 1c, 1e, 1i, 2a, 2h, 2j, $3 e, 3 \mathrm{~g}, 5 \mathrm{~d}, 5 \mathrm{e}, 5 \mathrm{i}, 5 \mathrm{u}, 8 \mathrm{~d}, 8 \mathrm{e}, 8 \mathrm{i}$ FLIGHT DATES: 4 May to 21 June 


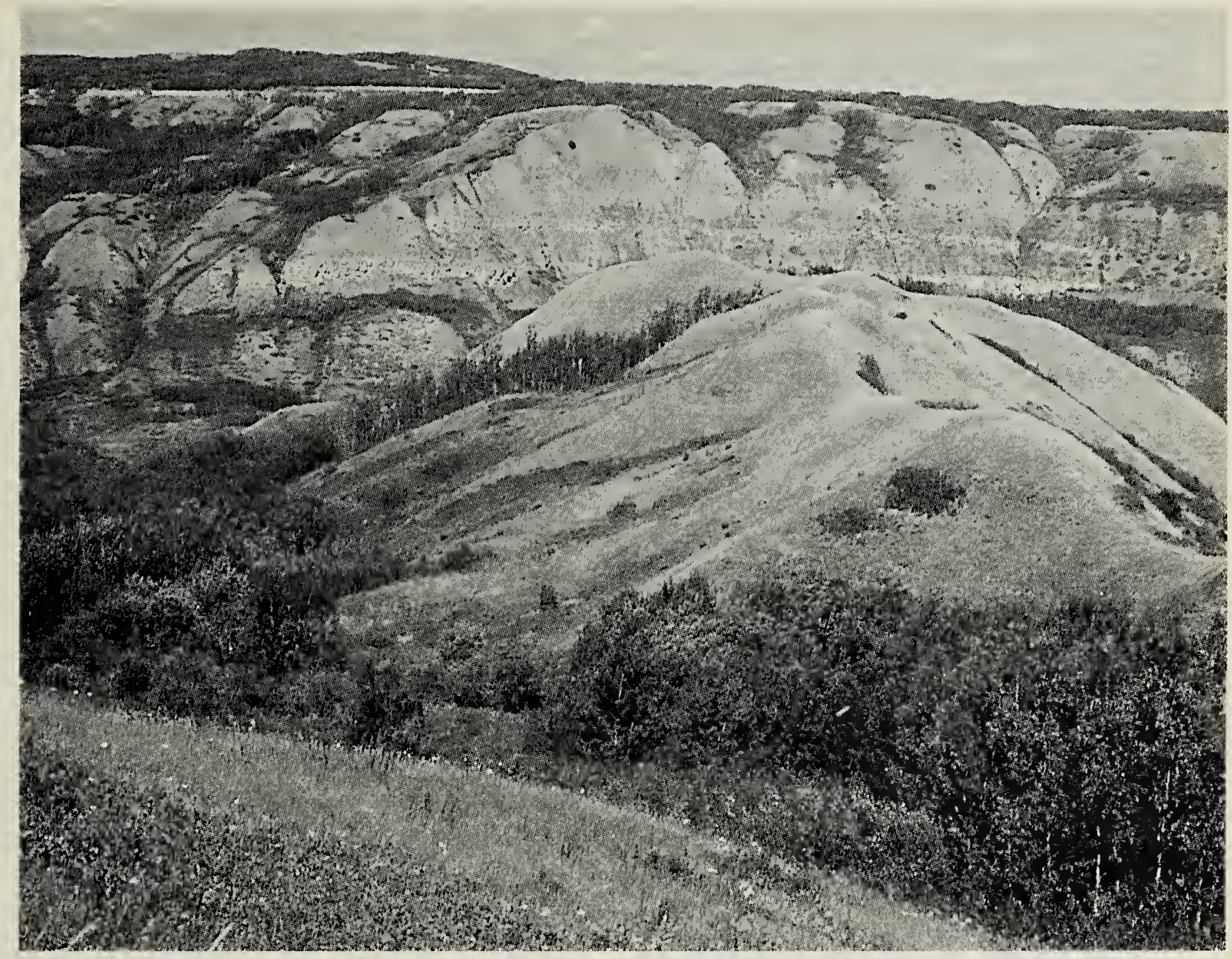

Beatton River valley northeast of Fort St. John, B.C.

N. Kondla

Persius Dusky Wing Erynnis persius (Scudder)

LOCALITIES: $1 \mathrm{e}, 1 \mathrm{~h}, 1 \mathrm{l}, 2 \mathrm{~h}, 3 \mathrm{e}, 4 \mathrm{~d}$, 8d, 8g, $8 \mathrm{i}$

FLIGHT DATES: 16 May to 21 June

Grizzled Skipper Pyrgus centaureae freija (Warren)

LOCALITIES: $2 \mathrm{j}$

FLIGHT DATES: 3 June

NOTES: This denizen of open black spruce bogs has only been found once in the study area, a few miles west of Goodlow, BC.

\section{Checkered Skipper Pyrgus commu-} nis (Grote)

LOCALITIES: 3g, 5f, 5h, 5i, 5j, $6 \mathrm{~g}$

FLIGHT DATES: 17 May to 25 August 25

NOTES: Adults of this species fly over the dry grasslands along the river valley, often visiting flowers of alfalfa which are used as nectar sources and as perching sites for males. The flight period is very long but it is unclear if this represents multiple broods or a staggered emergence. Previously, this taxon was known to occur as far north as Fort MacMurray and as far west as Edmonton.

Arctic Skipper Carterocephalus palaemon mandan (W.H. Edwards) LOCALITIES: 1k, 2h, 2j, 3a, 3g, 4k, $5 d, 5 h, 5 i, 5 j, 5 q, 5 u, 5 w, 8 e, 8 i$ FLIGHT DATES: 16 May to 26 June NOTES: Case and Bird indicate that, in their larger study, there is a great deal of variation within this species. ${ }^{3}$ Kondla listed the main differences between mandan and the unnamed mountain subspecies in Alberta. ${ }^{16}$ We have found in the Peace River region that there is little phenotypic variation. All specimens collected are small and light in colour. 
Garita Skipperling Oarisma garita (Reakirt)

LOCALITIES: 1c, 1e, 1f, 1k, 1l, 2a, 3h, 4e, 4k, 5d, 5f, 5h, 5i, 5j, 5u, 6f, 6g FLIGHT DATES: 31 May to 3 July

NOTES: Populations of this species appear to be largely confined to native grasslands, primarily along the Peace River valley and tributary stream valleys. They have not been collected in old fields or along highways or road sides any distance from native grassland. Adults differ from those collected in other areas of Alberta in that the dark areas of the ventral hind wing are greatly extended and much darker in specimens from the Peace River valley. Based on material collected, this taxon may warrant description as a distinct subspecies.

Assiniboia Skipper Hesperia assiniboia (Lyman)

LOCALITIES: 1e, 1f, 2a, 2d, 3h, 4e, $5 \mathrm{~d}, 5 \mathrm{~h}, 5 \mathrm{i}, 5 \mathrm{j}, 5 \mathrm{k}, 5 \mathrm{u}, 5 \mathrm{w}, 6 \mathrm{c}, 6 \mathrm{~g}$

FLIGHT DATES: 4 August to $26 \mathrm{Au}-$ gust

NOTES: Adults of this taxon are locally abundant on the grassy slopes of the Peace River valley, where they frequent flowers of alfalfa and Aster sp. The distinctive Peace River populations are assigned to this species due to their very light coloration, but they show consistent phenotypic differences from specimens of this species collected in southern Alberta. These differences include a strong tendency towards loss of silvering on the ventral surface, and a reduction of the orange colouring on the dorsal surface. The collection of $H$. assiniboia in the Peace River area is a range extension of about 550 $\mathrm{km}$, from Redwater, Alberta. ${ }^{15}$

Long Dash Polites mystic dacotah (W.H. Edwards)

LOCALITIES: 1b, 2c, 3a, 4h, 5d, 5h, $5 \mathrm{j}, 7 \mathrm{i}, 8 \mathrm{i}$
FLIGHT DATES: 19 June to 14 August

NOTES: Case and Bird report this taxon under the name $P$. sonora dacotah. $^{3}$ On 14 June 1981, two fresh specimens were collected at Dunvegan. Both individuals were puddling at alkali seepages at the base of a steep grassy slope locally known as Dunvegan Hill. In 1983 specimens appeared to be more abundant, and were seen or collected along margins of aspen forests.

Roadside Skipper Amblyscirtes vialis (W.H. Edwards)

LOCALITIES: 4j, 5d, 5i, 5j, 6g, 7b, 7i, 8d, 8i

FLIGHT DATES: 20 May to 23 June

NOTES: This species has not yet been found in the portion of the study area in British Columbia.

\section{Papilionidae}

Old World Swallowtail Papilio machaon pikei Sperling LOCALITIES: $1 \mathrm{a}^{\star}, 1 \mathrm{c}^{\star}, 1 \mathrm{e}^{\star}, 1 \mathrm{f}^{\star}, 2 \mathrm{a}^{*}$, $5 f^{\star}, 5 \mathrm{~g}^{\star}, 5 \mathrm{~h}^{\star}, 5 \mathrm{j}^{\star}, 6 \mathrm{f}^{\star}, 6 \mathrm{~g}^{\star}, 7 \mathrm{~b}^{\star}, 7 \mathrm{i}$ (asterisks indicate larval records)

FLIGHT DATES: 30 May to 14 July NOTES: This race of Papilio machaon is endemic to the eroding valley sides and badlands of the Peace River area. It was originally reported by Llewellyn-Jones as $P$. machaon oregonius; and by Case and Bird, and Case and Case as $P$. machaon hudsonianus. ${ }^{3,4,21}$ Sperling described it as a patronym of Edward M. Pike. ${ }^{37}$ P. m. pikei is intermediate among $P$. $m$. hudsonianus, $P$. m. aliaska and P. m. oregonius in wing shape and colour markings, and is best separated by habitat and locality.

Populations can be found wherever 
dense patches of its larval host plant, linear-leaved wormwood (Artemisia dracunculus), can be found. Small larvae have been found as early as July 8 , and all instars have been found in August. ${ }^{40}$ Larvae collected in early September had a high rate of parasitism by large black ichneumon wasps (Trogus sp.). Adults nectar at alfalfa (Medicago sativa). Males are easily found while they patrol for females along the upper edge of prominent, south-facing valley slopes or sometimes also at host plant patches at the base of grassy slopes.

\section{Zelicaon Swallowtail Papilio zeli-} caon Lucas

LOCALITIES: $1 \mathrm{a}^{*}, 1 \mathrm{~d}^{*}, 1 \mathrm{e}, 1 \mathrm{~g}^{*}, 11$, $2 \mathrm{~h}, 3 \mathrm{a}^{*}, 3 \mathrm{~b}^{*}, 3 \mathrm{e}, 3 \mathrm{f}^{*}, 3 \mathrm{~g}, 4 \mathrm{a}^{*}, 4 \mathrm{c}^{*}$, $4 \mathrm{~g}^{\star}, 4 \mathrm{~h}^{\star}, 4 \mathrm{i}^{\star}, 5 \mathrm{f}, 6 \mathrm{a}^{*}, 6 \mathrm{~g}, 7 \mathrm{k}, 7 \mathrm{~m}^{\star}$ (asterisks indicate larval records)

FLIGHT DATES: 17 May to 9 July

NOTES: Larvae of all instars can be found throughout July. Adults have been reared from larvae collected on cow parsnip (Heracleum lanatum), heart-leaved Alexanders (Zizia aptera) and water parsnip (Sium suave). $P$. zelicaon generally flies in mixed forest and parkland. $P$. zelicaon and $P$. machaon adults have been collected together at several localities along the high, grassy slopes of the Peace River valley and a small number of hybrids have been collected. $^{39}$

Canadian Swallowtail Papilio canadensis Rothschild and Jordan

LOCALITIES: 1c, 1e, 1f, 1h, 1i, 1l, $1 \mathrm{k}, 1 \mathrm{j}, 2 \mathrm{a}, 2 \mathrm{e}, 2 \mathrm{~h}, 3 \mathrm{a}, 3 \mathrm{~b}, 3 \mathrm{~d}, 3 \mathrm{e}, 3 \mathrm{~g}$, $4 \mathrm{~b}, 4 \mathrm{e}, 4 \mathrm{k}, 5 \mathrm{~d}, 5 \mathrm{f}, 5 \mathrm{~g}, 5 \mathrm{~h}, 5 \mathrm{i}, 5 \mathrm{j}, 5 \mathrm{k}$, $5 \mathrm{u}, 5 \mathrm{w}, 6 \mathrm{e}, 6 \mathrm{f}, 6 \mathrm{~g}, 7 \mathrm{a}, 7 \mathrm{c}, 7 \mathrm{~d}, 7 \mathrm{i}, 7 \mathrm{k}$, $7 \mathrm{n}, 8 \mathrm{c}, 8 \mathrm{~d}, 8 \mathrm{e}, 8 \mathrm{~g}, 8 \mathrm{~h}, 8 \mathrm{i}$

FLIGHT DATES: 15 May to 14 July

NOTES: This species seems to be generally distributed throughout the study area. Adults are found in all habitats. An adult was reared from an egg that was observed being oviposited on a small aspen poplar leaf about one metre above the ground at La Crete ferry. Traditionally reported in the literature as a subspecies of Papilio glaucus but recently the taxon canadensis has been shown to be a distinct species. ${ }^{12}$

\section{Pieridae}

Western Checkered White Pieris occidentalis Reakirt

LOCALITIES: 1c, 1e, 1f, 1k, 2a, 3e, $3 \mathrm{~g}, 3 \mathrm{~h}, 4 \mathrm{e}, 4 \mathrm{k}, 5 \mathrm{f}, 5 \mathrm{~g}, 5 \mathrm{i}, 5 \mathrm{j}, 5 \mathrm{r}, 5 \mathrm{u}$, $5 \mathrm{z}, 6 \mathrm{~g}, 7 \mathrm{a}, 7 \mathrm{~b}, 7 \mathrm{c}, 7 \mathrm{i}, 7 \mathrm{k}, 8 \mathrm{i}, 8 \mathrm{~g}$ FLIGHT DATES: 4 April to 8 September

NOTES: This species was listed under the name $P$. protodice occidentalis. ${ }^{3}$ It is here treated as a separate species in accordance with accepted classification. ${ }^{14,24}$ There are at least two broods. Early spring brood individuals are smaller and more heavily marked with dark scales on the ventral hind wing than butterflies of the summer brood which are larger and lighter.

Mustard White Pieris napi oleracea Harris

LOCALITIES: 3g, 5d, 5e, 5i, 5q, 5u, $7 \mathrm{i}, 8 \mathrm{a}, 8 \mathrm{~g}, 8 \mathrm{~h}, 8 \mathrm{i}$

COLLECTION DATES: 3 May to 26 July

\section{Cabbage Butterfly Pieris rapae (Linnaeus) \\ LOCALITIES: 1e, 1f, 1k, 1n, 2a, 2f, 2j, 3e, 3g, 3h, 4d, 4e, 4k, 5d, 5f, 5h, $5 \mathrm{i}, 5 \mathrm{j}, 5 \mathrm{k}, 5 \mathrm{u}, 5 \mathrm{w}, 6 \mathrm{~b}, 6 \mathrm{~g}, 7 \mathrm{a}, 7 \mathrm{~b}, 7 \mathrm{c}$, $7 \mathrm{e}, 7 \mathrm{f}, 7 \mathrm{i}, 8 \mathrm{c}, 8 \mathrm{e}$}

FLIGHT DATES: 27 April to 29 September

NOTES: This introduced species is generally distributed throughout the Peace River valley. Adults can be 
very abundant, frequently visiting flowers of alfalfa in August, and larvae are considered pests of market garden crops. There are at least two broods, and perhaps as many as four.

\section{Large Marble Euchloe ausonides} Lucas

LOCALITIES: 1c, 1i, 2a, 2c, 2e, 2h, 3e, 3g, 4e, 5d, 5f, 5h, 5i, 5y, 6f, 7a, 7b, 7c, 7g, 7i, 8c, 8g, 8h

FLIGHT DATES: 16 May to 9 August NOTES: In June, if a large number of white butterflies is seen flying over an unploughed field in the Fairview area, it is certain that they are adults of this species, and not $P$. rapae. In some fields the adults are very abundant. Adults are also found in jackpine sandhills, aspen forests, and grasslands along the Peace River. Eggs are laid on budding inflorescences of Arabis drummondii Gray, one egg to a plant.

\section{Creusa Marble Euchloe creusa} (Doubleday)

LOCALITIES: $1 \mathrm{~h}$

COLLECTION DATES: 26 June

NOTES: So far only found in the Dunlevy area where the Peace River enters the Rocky Mountains.

\section{Clouded Sulphur Colias philodice} Godart

LOCALITIES: 1c, 1e, 1f, $1 \mathrm{j}, 1 \mathrm{k}, 1 \mathrm{l}$, 1n, 2a, 2e, 2h, 3a, 3b, 3e, 3g, 4e, 4k, $5 \mathrm{~d}, 5 \mathrm{f}, 5 \mathrm{~h}, 5 \mathrm{i}, 5 \mathrm{j}, 5 \mathrm{k}, 5 \mathrm{u}, 5 \mathrm{y}, 6 \mathrm{~g}, 7 \mathrm{~d}$, $7 \mathrm{i}, 7 \mathrm{~m}, 8 \mathrm{e}, 8 \mathrm{~g}, 8 \mathrm{i}$

FLIGHT DATES: 4 May to 29 September

NOTES: This species appears to have a small spring brood, at least two summer broods and sometimes a fall brood in the Peace country. Specimens of this species were reported as $C$. eurytheme. ${ }^{3}$

Christina Sulphur Colias christina Edwards
LOCALITIES: $1 \mathrm{e}, 1 \mathrm{~h}, 1 \mathrm{~m}, 2 \mathrm{a}, 2 \mathrm{e}, 2 \mathrm{f}$, 2h, 2j, 3a, 4b, 4c, 5d, 5h, 5y, 7a, 7e, $7 \mathrm{k}, 7 \mathrm{~m}, 8 \mathrm{i}$

FLIGHT DATES: 21 June to 12 August

NOTES: Specimens of this species were misidentified as $C$. eurytheme. ${ }^{3}$ The taxon alberta, described from the study area by Bowman as a subspecies of eurytheme, has been the subject of some debate in the literature. ${ }^{1}$ Besides having been viewed as a synonym of $C$. christina, it has been attached to both $C$. eurytheme and $C$. philodice vitabunda. ${ }^{24}$ As well it has been referenced as a hybrid situation. ${ }^{6}$ Kondla has reviewed this situation and determined that alberta is in fact allied with C. christina. ${ }^{17}$ This species, while widespread, is only locally common.

Canadian Sulphur Colias canadensis Ferris

LOCALITIES: $1 \mathrm{j}, 7 \mathrm{~m}^{8}$

FLIGHT DATES: 30 May to 4 July

NOTES: This recently described species has in the past been reported as Colias hecla.

Giant Sulphur Colias gigantea Strecker

LOCALITIES: 1j, 2j, 3a, 5d, 5g, 5j, 5y FLIGHT DATES: 14 June to 8 July

NOTES: Adults appear to have a very short flight period, and are almost universally restricted to wet willow fens and catchment marshes with willows.

Pink-edged Sulphur Colias interior Scudder

LOCALITIES: 1b, 2j, 3g, 4e, 5d, 7a, $7 \mathrm{~b}, 7 \mathrm{e}, 7 \mathrm{~m}$

FLIGHT DATES: 21 June to 5 August

Palaeno Sulphur Colias palaeno chippewa W.H. Edwards

FLIGHT DATES: June 18

NOTES: So far only found along 
Highway 2, $56 \mathrm{~km}$ SE of Dawson Creek in Alberta. ${ }^{10}$

\section{Bronze Copper Lycaena hyllus}

(Cramer)

LOCALITIES: $6 c$

FLIGHT DATES: 17 August

NOTES: A single battered male was collected in 1981. It could represent a local colony or a migrant. The specimen was collected while visiting alfalfa flowers near a marsh, and represents a range extension of about $320 \mathrm{~km}$. Kondla reports that the species does use fens in central Alberta and since this species is easy to overlook, it may well be established in fens and marshes in the study area. ${ }^{18}$

Purplish Copper Lycaena helloides (Boisduval)

LOCALITIES: 2a, 4k, 5i, 5j, 5w, 6c

FLIGHT DATES: 29 June, 14 August to 22 August

NOTES: The taxonomy of this species and $L$. dorcas has been the subject of conflicting interpretations. ${ }^{7,28}$ Based on work in Alberta we treat these two as distinct species. Specimens appear to be differentiated from populations in southern Alberta, but series are too short to be certain of constancy of differences.

\section{Dorcas Copper Lycaena dorcas} dorcas (W. Kirby)

LOCALITIES: $2 \mathrm{f}, 2 \mathrm{j}$

FLIGHT DATES: 6 July

NOTES: So far only found in a black spruce bog a few miles west of Goodlow, BC, and along Highway 64 just east of the $A B / B C$ border.

Mariposa Copper Lycaena mariposa (Reakirt)

LOCALITIES: 1h, 4e, 7e, 7f, 7m, 8e COLLECTION DATES: 25 June to 1 August

Coral Hairstreak Harkenclenus titus
(Fabricius)

LOCALITIES: 1c, 1e, 1f, 1k, 1l, 1n, 2a, 5d, 5 j, 6g, 8c

FLIGHT DATES: 28 June to 11 August

NOTES: Adults are consistently darker than adults of other populations in western North America. They appear to be otherwise similar. Due to the difference, description as a distinct subspecies may be warranted.

Adults are associated with the edge of native grassland, where they tend to perch on saskatoon bushes. Populations in the Fort St. John area were found to frequently display hilltopping behaviour which was not observed in those from the Peace River valley in Alberta.

Striped Hairstreak Satyrium liparops (Le Conte)

LOCALITIES: 1e, 1f, 1k, 11, 2a, 5d, 5j, 6g, 7a, 7i

FLIGHT DATES: 26 June to 26 July

NOTES: Individuals of this species, both male and female, are different from all other specimens examined from North America in that they are darker and have a more uniform wing pattern. They may be worthy of description as a distinct subspecies.

Adults perch on spreading dogbane and saskatoon and chokecherry bushes. They do not hilltop as regularly as $H$. titus but do engage in this behaviour. They also appear to be territorial, and chase individuals of any insect species out of their territory.

Brown Elfin Callophrys augustinus (Westwood)

LOCALITIES: 3e, 5c, 5d, 5e, 5o, 7j, $8 \mathrm{e}, 8 \mathrm{~g}$

FLIGHT DATES: 3 May to 12 June

NOTES: Adults of this species are found in wet and boggy areas near 
spruce and poplar forests, and in jackpine forests.

Hoary Elfin Callophrys polios obscurus (Ferris and Fisher)

LOCALITIES: 2 a, 3e, 5d, 5e, 5j, 5o, $5 y, 7 a, 7 c$

FLIGHT DATES: 26 April to 8 June

Eastern Pine Elfin Callophrys niphon clarki Freeman

LOCALITIES: $5 d, 50,71$

FLIGHT DATES: 13 May to 23 May

NOTES: On comparison with adults of this subspecies from Clyde, Alberta, 11 specimens clearly represent this taxon. Their collection extends the range of this species westward from Wood Buffalo National Park and Clyde, AB.

Western Pine Elfin Callophrys eryphon (Boisduval)

LOCALITIES: 2a, 4j, 5d, 50

FLIGHT DATES: 9 May to 19 June

NOTES: The occurrence of this species sympatrically with the preceding species raises the possibility of hybridization as suggested by Reist. ${ }^{27}$ A single specimen taken north of Manning may also be referable to this species. Further study is required to clarify the relationship between these two species in northern Alberta.

Western Tailed Blue Everes amyntula albrighti Clench

LOCALITIES: 1c, 1d, 1e, 1f, 1h, 1i, $1 \mathrm{k}, 1 \mathrm{l}, 2 \mathrm{a}, 2 \mathrm{e}, 2 \mathrm{~h}, 2 \mathrm{j}, 3 \mathrm{a}, 3 \mathrm{~b}, 3 \mathrm{~d}, 3 \mathrm{e}$, $3 \mathrm{~g}, 4 \mathrm{~d}, 4 \mathrm{e}, 5 \mathrm{~d}, 5 \mathrm{e}, 5 \mathrm{~g}, 5 \mathrm{~h}, 5 \mathrm{i}, 5 \mathrm{j}, 5 \mathrm{u}$, $5 \mathrm{x}, 5 \mathrm{y}, 6 \mathrm{f}, 6 \mathrm{~g}, 7 \mathrm{a}, 7 \mathrm{i}, 7 \mathrm{~m}, 8 \mathrm{c}, 8 \mathrm{~d}, 8 \mathrm{e}$, $8 \mathrm{~g}, 8 \mathrm{~h}, 8 \mathrm{i}$

FLIGHT DATES: 11 May to 1 August

Spring Azure Celastrina argiolus lucia (Kirby)

LOCALITIES: 1e, 2a, 2j, 3g, 4e, 5d, 5 e, 5i, 5j, 5k, 5o, 5u, 5y, 7l, 8g

FLIGHT DATES: 7 April to 11 June

NOTES: Recent literature treats lucia as a subspecies of $C$. argiolus. However recent research $(\mathrm{H}$. Pavulaan, pers. comm.; Kondla, unpublished) shows that argiolus actually consists of a species complex and that lucia may be a distinct species. ${ }^{30}$

Silvery Blue Glaucopsyche lygdamus couperi Grote

LOCALITIES: 1c, $1 \mathrm{e}, 1 \mathrm{f}, 1 \mathrm{~h}, 1 \mathrm{i}, 1 \mathrm{k}$, $1 \mathrm{l}, 2 \mathrm{a}, 2 \mathrm{c}, 2 \mathrm{e}, 2 \mathrm{~h}, 2 \mathrm{j}, 3 \mathrm{a}, 3 \mathrm{~b}, 3 \mathrm{e}, 3 \mathrm{~g}$, $4 e, 4 k, 5 d, 5 e, 5 f, 5 h, 5 i, 5 j, 50,5 p$, $5 \mathrm{u}, 5 \mathrm{w}, 5 \mathrm{y}, 6 \mathrm{f}, 6 \mathrm{~g}, 7 \mathrm{a}, 7 \mathrm{c}, 7 \mathrm{~h}, 7 \mathrm{i}, 7 \mathrm{j}$, $8 \mathrm{a}, 8 \mathrm{c}, 8 \mathrm{e}, 8 \mathrm{~g}, 8 \mathrm{~h}, 8 \mathrm{i}$

FLIGHT DATES: 26 April to 14 July NOTES: Widely distributed in most habitats. Recent work suggests that the taxon couperi may be a distinct species from $G$. lygdamus. ${ }^{5}$

Northern Blue Plebejus idas scudderi (Edwards)

LOCALITIES: $1 \mathrm{e}, 1 \mathrm{~h}, 2 \mathrm{j}, 2 \mathrm{~h}, 4 \mathrm{e}, 5 \mathrm{~d}$, $6 \mathrm{~g}, 7 \mathrm{e}, 7 \mathrm{f}, 7 \mathrm{~m}, 8 \mathrm{c}, 8 \mathrm{e}, 8 \mathrm{f}$

FLIGHT DATES: 21 June to 11 August

NOTES: Case and Bird report specimens of this species as $P$. melissa. ${ }^{3}$ Their specimens have been re-examined and they are all females of P. idas.

Greenish Blue Plebejus saepiolus amica (W.H. Edwards)

LOCALITIES: 1a, 1b, 1c, 1d, 1e, 1f, $1 \mathrm{~h}, 1 \mathrm{i}, 1 \mathrm{j}, 2 \mathrm{a}, 2 \mathrm{c}, 2 \mathrm{e}, 2 \mathrm{~h}, 2 \mathrm{j}, 3 \mathrm{a}, 3 \mathrm{~b}$, 3c, 3d, 3h, 4d, 4e, 4f, 5d, 5f, 5h, 5i, $5 \mathrm{u}, 5 \mathrm{x}, 5 \mathrm{y}, 6 \mathrm{f}, 6 \mathrm{~g}, 7 \mathrm{~b}, 7 \mathrm{e}, 7 \mathrm{i}, 7 \mathrm{k}, 7 \mathrm{~m}$, 8b, 8c, 8e, 8g, 8i, 8k

FLIGHT DATES: 30 May to 26 July

NOTES: One of the ubiquitous species in the region.

Rustic Blue Plebejus rusticus (W.H. Edwards)

LOCALITIES: 1c, 1e, 1f, 2a, 3a, 3e, 4b, 4e, 5d, 5e, 5f, 5h, 5i, 5j, 6f, 7i, 8i FLIGHT DATES: 11 May to 12 July NOTES: A variety of genus and species names that have been applied to this taxon in recent years. ${ }^{19}$ 
Populations in the study area appear most closely allied with subspecies rusticus but work is needed to clarify the most appropriate subspecies nomenclature.

Adults fly on the native grasslands along the Peace River valley, and can also be found in jackpine sandhills. Colonies are small and do not appear to be numerous.

\section{Nymphalidae}

Great Spangled Fritillary Speyeria cybele pseudocarpenteri ( $F$. and R. Chermock)

LOCALITIES: 1e, 1f, 1k, 2a, 2d, 2j, $3 \mathrm{~g}, 4 \mathrm{e}, 5 \mathrm{~d}, 5 \mathrm{~h}, 5 \mathrm{i}$

FLIGHT DATES: 28 June to 27 August

NOTES: This very aggressive flier can be found in shrub thickets on valley slopes, poplar draws on valley sides and upland poplar forest. Unlike individuals from more southern populations, adults in this study area very seldom nectar at flowers.

Aphrodite Fritillary Speyeria aphrodite manitoba ( $\mathrm{F}$. and $\mathrm{R}$. Chermock) LOCALITIES: $1 \mathrm{e}, 1 \mathrm{f}, 1 \mathrm{~h}, 1 \mathrm{k}, 1 \mathrm{l}, 1 \mathrm{~m}$, 2a, 2j, 5d, 5e, 5g, 5h, 5i, 5j, 5u, 8i FLIGHT DATES: 6 July to 7 September

NOTES: In the Peace River country adults of this species fly primarily in late July and early August, after the majority of adults of $S$. electa disappear. Its discovery in the Peace River region is a major range extension, and due to the habitat information provided by Kondla we expect that future field work in intervening areas will confirm that the Peace River populations are in fact disjunct from others. ${ }^{18}$

Boreal Fritillary Speyeria hollandi
(F. and R. Chermock)

LOCALITIES: $1 \mathrm{e}, 2 \mathrm{j}, 5 \mathrm{~d}, 5 \mathrm{e}, 7 \mathrm{a}, 7 \mathrm{~b}$, $7 \mathrm{e}, 7 \mathrm{i}, 7 \mathrm{~m}, 8 \mathrm{a}, 8 \mathrm{~b}, 8 \mathrm{c}, 8 \mathrm{~d}, 8 \mathrm{e}, 8 \mathrm{f}, 8 \mathrm{i}$

FLIGHT DATES: 22 June to 21 August

NOTES: This species is usually found in boggy or heavily wooded areas. The taxonomic and nomenclatural argument provided by Kondla is followed for this and the following species. ${ }^{18}$

Northwestern Fritillary Speyeria electa (W.H. Edwards)

LOCALITIES: 1b, 1c, 1e, 1f, 1h, 1k, $1 \mathrm{l}, 1 \mathrm{~m}, 2 \mathrm{a}, 2 \mathrm{j}, 3 \mathrm{a}, 3 \mathrm{~b}, 3 \mathrm{e}, 3 \mathrm{~g}, 3 \mathrm{~h}, 4 \mathrm{c}$, $4 e, 5 g, 5 h, 5 i, 5 j, 5 u, 5 y, 6 b, 6 f, 6 g$, $7 \mathrm{~b}, 7 \mathrm{i}$

FLIGHT DATES: 6 June to 1 August NOTES: Adults of this species appear in June with the flight period extending into July.

Mormon Fritillary Speyeria mormonia eurynome (W.H. Edwards)

LOCALITIES: $5 \mathrm{u}, 5 \mathrm{w}, 6 \mathrm{~g}$

FLIGHT DATES: 26 August

Bog Fritillary Boloria eunomia dawsoni (Barnes and McDunnough) LOCALITIES: $2 \mathrm{e}, 2 \mathrm{~h}, 5 \mathrm{~d}, 5 \mathrm{e}, 5 \mathrm{~g}, 5 \mathrm{y}$, $8 \mathrm{e}, 8 \mathrm{~g}$

FLIGHT DATES: 8 June to 23 June

Silver-bordered Fritillary Boloria selene (Denis and Schiffermueller) LOCALITIES: 1d, 2h, 3a, 3g, 4a, 5b, $5 \mathrm{~d}, 5 \mathrm{i}, 5 \mathrm{k}, 5 \mathrm{u}, 5 \mathrm{y}, 6 \mathrm{~b}, 7 \mathrm{a}, 7 \mathrm{~d}, 7 \mathrm{e}, 7 \mathrm{~m}$, 8 e

FLIGHT DATES: 6 June to 25 July

Meadow Fritillary Boloria bellona jenistae Stallings and Turner

LOCALITIES: 1c, 1f, 1l, 2a, 2h, 3e, $3 \mathrm{~g}, 4 \mathrm{e}, 5 \mathrm{~d}, 5 \mathrm{e}, 5 \mathrm{~h}, 5 \mathrm{i}, 5 \mathrm{j}, 5 \mathrm{u}, 5 \mathrm{v}, 6 \mathrm{f}$ $6 \mathrm{~g}, 7 \mathrm{a}, 7 \mathrm{~b}, 7 \mathrm{i}, 8 \mathrm{c}, 8 \mathrm{e}, 8 \mathrm{~g}, 8 \mathrm{~h}, 8 \mathrm{i}$

FLIGHT DATES: 9 May to 28 June; 13 August to 25 August

NOTES: In the Peace River country this species is double brooded. Adults fly in old fields, forest 
openings, and edges of grassland areas. Pike found that eggs are laid on violets.

Frigga's Fritillary Boloria frigga saga (Staudinger)

LOCALITIES: 2i, 2j, 3g, 5d, 5e, 5h, $5 y, 8 g, 8 j$

FLIGHT DATES: 19 May to 23 June

Freija Fritillary Boloria freija (Thunberg)

LOCALITIES: 2a, 2i, 2j, 3g, 4e, 5c, $5 \mathrm{~d}, 5 \mathrm{e}, 5 \mathrm{o}, 5 \mathrm{y}, 7 \mathrm{a}, 7 \mathrm{c}, 7 \mathrm{l}, 7 \mathrm{n}, 8 \mathrm{~g}, 8 \mathrm{~h}$

FLIGHT DATES: 26 April to 11 June

Purple Fritillary Boloria titania grandis (Barnes and McDunnough)

LOCALITIES: $2 \mathrm{f}, 2 \mathrm{j}, 5 \mathrm{~d}, 5 \mathrm{e}, 7 \mathrm{e}, 7 \mathrm{f}$, $7 \mathrm{~m}, 8 \mathrm{i}$

FLIGHT DATES: 17 June to 23 August

\section{Gorgone Checkerspot Chlosyne} gorgone (Huebner)

LOCALITIES: 5i, 5h

FLIGHT DATES: 17 May to 26 June

NOTES: An uncommon and local species in Alberta, adults are rarely collected in series. In 1980, a small colony was discovered at Green Island. Extensive investigations yielded another small colony at Dunvegan in 1983. These are the only known colonies in the Peace River region to date.

The colonies cover an area of about 1/4 ha, and within that area, adults are fairly abundant. Outside of that area, adults are rarely encountered. In over 100 hours of collecting, only one specimen has ever been seen over $100 \mathrm{~m}$ from a colony.

\section{Northern Checkerspot Chlosyne} palla (Boisduval)

LOCALITIES: 1c,1k, 2a, 5f, 5h, 5j, $6 \mathrm{~g}, 7 \mathrm{a}, 7 \mathrm{i}, 8 \mathrm{c}, 8 \mathrm{i}$

FLIGHT DATES: 23 May to 14 July

NOTES: Although Case and Bird fail to report this species, the first known specimen was collected by J. Belicek at Peace River town site in 1973, and a series of over 100 specimens now exists in collections. Adults primarily inhabit valley-side poplar forests where the presumed food plant, Aster conspicuous, grows in the understorey. However, adults are best observed at the poplar forest/grassland interface where they visit flowers of alfalfa and spreading dogbane and Senecio sp.

There is some question as to the correct placement of this taxon. It is clearly distinct from both $C$. palla in southern Alberta and British Columbia, but it is also distinct from $C$. acastus from southern Alberta prairies. It is placed with $C$. palla largely because Alberta $C$. acastus has a monotone orange ground color on the dorsal surface, and $C$. palla has a two-toned ground color. The Peace River material has a two-toned ground color.

Northern Crescent Phyciodes morpheus (Drury)

LOCALITIES: 1a, 1b, 1d, 1e, 1f, 1h, $1 \mathrm{k}, 2 \mathrm{~b}, 2 \mathrm{e}, 2 \mathrm{~h}, 2 \mathrm{j}, 3 \mathrm{a}, 3 \mathrm{~b}, 3 \mathrm{e}, 3 \mathrm{~g}, 4 \mathrm{c}$, $4 \mathrm{e}, 5 \mathrm{~d}, 5 \mathrm{f}, 5 \mathrm{~g}, 5 \mathrm{~h}, 5 \mathrm{i}, 5 \mathrm{j}, 5 \mathrm{k}, 5 \mathrm{u}, 5 \mathrm{x}$, $6 \mathrm{~b}, 6 \mathrm{f}, 6 \mathrm{~g}, 6 \mathrm{~h}, 7 \mathrm{a}, 7 \mathrm{c}, 7 \mathrm{e}, 7 \mathrm{i}, 7 \mathrm{k}, 8 \mathrm{~b}$, $8 \mathrm{c}, 8 \mathrm{e}, 8 \mathrm{f}, 8 \mathrm{~g}, 8 \mathrm{i}$

FLIGHT DATES: 28 May to 23 August

NOTES: Adults are found in or near forested areas, and at the edges of poplar forests along river bottoms.

Tawny Crescent Phyciodes batesii (Reakirt)

LOCALITIES: 1c, 1e, 1f, 1k, 1l, 2a, 2 j, 3e, 4b, 4e, 5j, 5h, 5i, 6g, 7a, 7i

FLIGHT DATES: 23 May to 14 July NOTES: Larvae are web spinners, which is a reliable character in separating this species from the preceding one. This species is found around the shrubs of the grasslands, 
and is not often found flying with $P$. morpheus.

Field Crescent Phyciodes pratensis (Behr)

LOCALITIES: $1 \mathrm{~h}$

FLIGHT DATES: 26 June

NOTES: So far only found in the Dunlevy area.

Satyr Anglewing Polygonia satyrus (W.H. Edwards)

LOCALITIES: $1 \mathrm{~h}, 3 \mathrm{~g}, 4 \mathrm{~b}, 5 \mathrm{~d}, 5 \mathrm{e}, 5 \mathrm{l}$, 5j, 6g, 7a, 7c

FLIGHT DATES: 17 April to 30 June (hibernating generation), and 15 July to 18 August (new generation).

NOTES: Adults are found in any forested area where shaded stinging nettles are found. Pike confirmed stinging nettle as a larval food plant in this area.

Green Comma Polygonia faunus (W.H. Edwards)

LOCALITIES: 1f, 1h, 2a, 5d, 7b, 8a

FLIGHT DATES: 11 April to 17 August

Hoary Comma Polygonia gracilis Grote and Robinson

LOCALITIES: 3g, 5e, 8j

FLIGHT DATES: 21 April to 11 June NOTES: Specimens are provisionally listed under this taxon for lack of a better available name. Individuals from most parts of the boreal forest in northern Alberta and British Columbia are black and gray on the ventral surface while nominate gracilis is two-toned brown on the ventral surface. More work is needed on the taxa gracilis and zephyrus in this part of the continent. ${ }^{18}$

\section{Gray Comma Polygonia progne} (Cramer)

LOCALITIES: $1 \mathrm{f}, 2 \mathrm{a}, 3 \mathrm{~g}, 5 \mathrm{~d}, 5 \mathrm{i}, 5 \mathrm{j}$, $6 \mathrm{~g}, 8 \mathrm{i}$

FLIGHT DATES: 17 April to 26 August
NOTES: Adults are found in and near poplar forests where willow is growing.

Compton Tortoise Shell Nymphalis vau-album (Denis and Schiffermueller)

LOCALITIES: 1e, 1h, 3g, 4 e, 5d

FLIGHT DATES: 24 May to 17 August

Mourning Cloak Nymphalis antiopa (Linnaeus)

LOCALITIES: 1e, 1f, 2a, 3g, 4b, 4e, 5d, 5h, 5i, 5j, 5k, 5w, 5z, 6g, 8c

FLIGHT DATES: 16 April to 23 August

Milbert's Tortoise Shell Nymphalis milberti (Say)

LOCALITIES: $1 \mathrm{e}, 1 \mathrm{f}, 1 \mathrm{~h}, 1 \mathrm{j}, 2 \mathrm{f}, 2 \mathrm{~h}$, $3 \mathrm{~g}, 4 \mathrm{e}, 4 \mathrm{k}, 5 \mathrm{~d}, 5 \mathrm{~h}, 5 \mathrm{i}, 6 \mathrm{~g}, 7 \mathrm{k}, 7 \mathrm{~m}$ FLIGHT DATES: 25 May to 14 August

Painted Lady Vanessa cardui (Linnaeus)

LOCALITIES: 1c, 1f, 1n, 2a, 5i, 5u, $5 \mathrm{~W}$

FLIGHT DATES: 28 May to 8 September

NOTES: A large migration into the Peace River area occurred in 1979. Many fresh adults were seen throughout the area in August and September. Smaller migrations occurred in 1991 and 1992.

Red Admiral Vanessa atalanta rubria (Fruhstorfer)

LOCALITIES: $5 \mathrm{w}, 6 \mathrm{~g}, 8 \mathrm{c}, 8 \mathrm{e}, 8 \mathrm{~h}$

FLIGHT DATES: 10 June to 17 June

White Admiral Limenitis arthemis rubrofasciata (Barnes and McDunnough)

LOCALITIES: 1c, 1e, 1f, 1h, 1k, 1l, 2a, 2e, 2h, 2j, 3a, 3e, 3g, 4b, 4c, 4e, $5 \mathrm{~d}, 5 \mathrm{e}, 5 \mathrm{f}, 5 \mathrm{~g}, 5 \mathrm{~h}, 5 \mathrm{i}, 5 \mathrm{j}, 5 \mathrm{y}, 6 \mathrm{~b}, 6 \mathrm{~g}$, $7 \mathrm{a}, 7 \mathrm{~b}, 7 \mathrm{c}, 7 \mathrm{~h}, 7 \mathrm{i}, 7 \mathrm{k}, 8 \mathrm{e}, 8 \mathrm{i}$

FLIGHT DATES: 7 June to 11 August 
Inornate Ringlet Ceononympha inornata McDunnough

LOCALITIES: 1c, 1d, 1e, 1f, $1 \mathrm{i}, 1 \mathrm{j}$, $1 \mathrm{k}, 1 \mathrm{l}, 2 \mathrm{a}, 2 \mathrm{c}, 3 \mathrm{~b}, 3 \mathrm{e}, 3 \mathrm{~g}, 4 \mathrm{~b}, 4 \mathrm{c}, 4 \mathrm{~d}$, $4 e, 4 f, 4 k, 5 d, 5 f, 5 g, 5 h, 5 i, 5 j, 5 u$, $5 \mathrm{w}, 5 \mathrm{y}, 6 \mathrm{~d}, 6 \mathrm{f}, 6 \mathrm{~g}, 8 \mathrm{c}, 8 \mathrm{~g}, 8 \mathrm{i}$

FLIGHT DATES: 11 May to 16 July NOTES: Adults of this taxon appear to be somewhat differentiated from adults of this taxon from elsewhere in Alberta. There is a tendency to be darker, and a reduction or absence of eyespots on the forewing. This, at least, is true of populations from the native grasslands. Roadside populations do not show these tendencies. Thus there may be native and introduced populations with limited interaction between them.

Common Wood Nymph Cercyonis pegala ino (Hall)

LOCALITIES: 1e, 1f, 1k, 11, 2a, 2j, $3 \mathrm{~g}, 3 \mathrm{~h}, 4 \mathrm{i}, 5 \mathrm{~d}, 5 \mathrm{~h}, 5 \mathrm{i}, 5 \mathrm{j}, 5 \mathrm{k}, 5 \mathrm{u}, 5 \mathrm{w}$, 6d, 7a, 7b, 7f, 7i

FLIGHT DATES: 28 June to 23 August

NOTES: Specimens collected from native grasslands appear darker than specimens from southern Alberta, but specimens from road sides in the Alberta part of the region are much like the rest of the Alberta populations. Here, as in the preceding species, there may be native and introduced populations interacting.

Dark Wood Nymph Cercyonis oetus (Boisduval)

LOCALITIES: 1c, 1e, 1f, 1i, 1l, 1n, 2a FLIGHT DATES: 4 July to 11 August NOTES: This species seems to be restricted to the $B C$ side of the Peace River valley, and many adults are substantially darker than adults from other areas of British Columbia and Alberta.

Disa Alpine Erebia disa mancina Doubleday

LOCALITIES : 2j
FLIGHT DATES: 3 June

NOTES: So far only found in a spruce bog west of Goodlow, BC. Relatively little work was done in spruce bogs and this species is certainly more widely distributed in the region than this one record would indicate.

Red Disked Alpine Erebia discoidalis macdunnoughi Dos Passos LOCALITIES: 1g, 1j, 2j, 3g, 5c, 5d, $5 e, 5 i, 5 u, 5 y, 7 i, 7 l$

FLIGHT DATES: 26 April to 24 May

NOTES: This species was reared by Pike (unpublished), and the life cycle photographed and described. The most noteworthy point of the life cycle is that mature larvae spin flimsy cocoons before pupating.

Common Alpine Erebia epipsodea freemani Erhlich

LOCALITIES: 1c, $1 \mathrm{e}, 1 \mathrm{f}, 1 \mathrm{~h}, 1 \mathrm{i}, 1 \mathrm{j}$, 1k, 1l, 2a, 3g, 3h, 4b, 4d, 4e, 4k, 5d, $5 f, 5 \mathrm{~h}, 5 \mathrm{i}, 5 \mathrm{j}, 5 \mathrm{u}, 5 \mathrm{w}, 5 \mathrm{y}, 7 \mathrm{i}, 7 \mathrm{l}$

FLIGHT DATES: 13 May to 28 June

Macoun's Arctic Oeneis macounii (W.H. Edwards)

LOCALITIES: 4j, 5e, 8e, $8 \mathrm{i}$

FLIGHT DATES: 11 June to 20 June NOTES: Adults fly in the vicinity of jackpine sandhills and will hilltop.

Uhler's Arctic Oeneis uhleri (Reakirt)

LOCALITIES: $1 \mathrm{c}, 1 \mathrm{e}, 1 \mathrm{f}, 1 \mathrm{k}, 1 \mathrm{l}, 2 \mathrm{a}$, 4b, 4e, 5f, 5h, 5i, 5j, 6g, 7i

FLIGHT DATES: 7 May to 3 July

NOTES: Adults from the Peace River valley are distinct from adults collected in other parts of Alberta in that they are mostly larger, darker and have more eyespots.

Females oviposit on many species of grasses, and eggs take about three weeks to hatch. Mature larvae pupate in early May. 
Alberta Arctic Oeneis alberta Elwes LOCALITIES: $2 \mathrm{a}, 4 \mathrm{e}, 5 \mathrm{~d}, 5 \mathrm{e}, 5 \mathrm{i}, 5 \mathrm{j}$, $5 \mathrm{z}, 6 \mathrm{f}, 6 \mathrm{~g}$

FLIGHT DATES: April 26 to June 18 NOTES: First reported by Kondla from Kleskun Hill. Adults of this taxon are locally common along the Peace River in the native grasslands from Clayhurst to Peace River. They are also found occasionally in jackpine sandhills. This is one of the first butterflies to fly in the spring. Females oviposit on many species of grasses, and eggs hatch in about 30 days. Mature larvae overwinter and pupation occurs in early April, often before the snow has completely melted.

Peace River populations may represent a distinct subspecies which is being investigated by Pike.

Jutta Arctic Oeneis jutta ridingiana F. and R. Chermock LOCALITIES: 2j, 5d, 5e, $8 \mathrm{e}$ FLIGHT DATES: 3 June to 13 June

Discussion A total of 76 species have now been documented for this study area. We have not included a number of taxa collected by K. Bowman in 1925 at an undetermined location near Fort Vermilion. Although specimens are in the collection of the University of Alberta, the exact locality where these were collected is unknown and may not be within the study area as defined herein. Efforts by the writers and G.J. Hilchie to find the source of Bowman's records, both in the field and through file information, have been unsuccessful.

Only a few species are candidates for future addition to the fauna of the study area:

Manitoba Skipper Hesperia comma manitoba (Scudder) - MacNeil reports one female collected 24 August 1961 at Hotchkiss River. ${ }^{22}$ We treat this as a hypothetical species at this time because we have not been able to verify the identification and this taxon is known from only one other location in the boreal forest of Alberta. The flight date strongly suggests that this specimen could be $\mathrm{H}$. assiniboia. The taxonomy of Hesperia in North America needs more work, especially to determine relationships (if any) to European Hesperia comma.

Peck's Skipper Polites peckius (W. Kirby) - This species has been found north, south, east and west of the study area, so it is just a matter of time before it is discovered here. It should be looked for in fens, marshes and moist meadows.

California White Pieris sisymbrii (Boisduval) - Specimens were collected by $\mathrm{K}$. Bowman in the vicinity of Fort Vermilion and further work may yet confirm the presence of this species in the study area.

Melissa Blue Plebejus melissa W.H. Edwards - Two males and one female collected by $K$. Bowman at Wembly in 1925 appear to be of this species. Genitalia have not been examined and more work is needed to clarify whether or not this species does occur in the study area.

Yukon Blue Plebejus optilete yukona (Holland) - This species has been found northwest, east and southeast of the study area. Field work in spruce bogs during early July will likely turn up populations in the study area.

Chryxus Arctic Oeneis chryxus caryi Dyar - Specimens were collected by $\mathrm{K}$. Bowman in the general 
area of Fort Vermilion. This species was reported by Case and Bird but we have been unable to verify their record. $^{3}$ Additional exploration of pine forests in June is needed to determine if this taxon occurs in the study area.

Analysis of the adult flight phenology data (Table 2) shows that two-thirds of the species are on the wing in late June. Relatively high species diversity can be observed from mid-May through early July. Substantially fewer species are on the wing in late April to early May and mid-July to late August.

The northern limit of the study area is almost as far north as Churchill, Manitoba, which is well known for its arctic and subarctic butterflies. The Peace River region is unique as a northern area due to its high species diversity and due to disjunct and range-edge populations of species that are distinctly southern in their primary distribution. Thus the study area is at the limits of the range of 23 taxa.

Taxa which are at the northern and northwestern limits of their range here are: $O$. garita, $H$. assiniboia, $P$. mystic dacotah, $A$. vialis, $H$. titus, $S$. liparops, S. cybele pseudocarpenteri, C. pegala, $O$. uhleri ssp., and $O$. alberta. $S$. aphrodite manitoba, $P$. batesii and $C$. inornata $\mathrm{nr}$. benjamini are at their western and northwestern range limits here. The following taxa are at their northwestern range limits here: $P$. communis, L. hyllus, L. helloides, P. rusticus nr. rusticus, C. gorgone. Three taxa are at their northern range limits here: $P$. zelicaon, C. palla, and $C$. oetus. $C$. niphon and $E$. epipsodea freemani are at their western range limits. It is interesting to note that none of the taxa in the study area are at their southern or southeastern range limits here.

Ten of these taxa are also clearly disjunct for distances of 200 to 500 $\mathrm{km}$ from the nearest related populations to the south and southeast: $P$. communis, $O$. garita, $H$. assiniboia, $P$. machaon pikei, $H$. titus, $S$. liparops, C. gorgone, C. palla, $O$. uhleri and $O$. alberta. These same taxa also have highly circumscribed distributions within the study area, being wholly or largely confined to the Peace River valley and, in some cases, nearby tributary stream valleys. Cercyonis oetus is also disjunct but is limited to the western part of the study area and flies outside of the Peace River lowlands as well. Five taxa may be disjunct but additional work in areas to the east and southeast is needed to clarify this: $L$. hyllus, $L$. helloides, $P$. rusticus $\mathrm{nr}$. rusticus, $S$. aphrodite manitoba, and C. inornata nr. benjamini.

1. BOWMAN, K. 1942. A note on Colias eurytheme Bdv., with description of a new race (Lepidoptera, Pieridae). Can. Ent. 74:25.

2. - 1951. An annotated list of the Lepidoptera of Alberta. Can. J. of Zoology 29:121-165.

3. CASE, J.W. and C.D. BIRD. 1977. Butterflies and skippers of west-central Alberta. Blue Jay 35:208-219.

4. CASE, V. and J. CASE. 1980. Bear Canyon Area. pp.284-285 in SPALDING, D. A. E. (senior editor). A nature guide to Alberta. Provincial Museum of Alberta Publication No. 5. Hurtig, Edmonton. 368 pp.

5. DIRIG, R. and J.F. CRYAN. 1991. The status of Silvery Blue subspecies (Glaucopsyche lygdamus lygdamus and G. I. couperi: Lycaenidae) in New York. J. of the Lepidopterists' Soc. 45:272-290.

6. FERRIS, C.D. 1972. Notes on certain species of Colias (Lepidoptera, Pieridae) found in Wyoming and associated regions. Bull. of the Allyn Museum 5:1-23. 
7. 1977. Taxonomic revision of the species dorcas Kirby and helloides Boisduval in the genus Epidemia Scudder (Lycaenidae:Lycaeninae). Bull. of the Allyn Museum 45:1-42.

8. - 1982. Revision of North American Colias hecla Lefebvre (Pieridae: Coliadinae). Bull. of the Allyn Museum 71:1-19.

9. 1987. A revision of the North American Salix-feeding Colias species (Pieridae:Coliadinae). Bull. of the Allyn Museum 112:1-25.

10. - 1988a. Revision of several North American leguminosae-feeding Colias species, with description of a new subspecies (Pieridae:Coliadinae). Bull. of the Allyn Museum 116:1-28.

11. 1988b. Revision of the North American Ericaciae[sic]-feeding Colias species (Pieridae:Coliadinae). Bull. of the Allyn Museum 122:1-34.

12. HAGEN, R.H., R.C. LEDERHOUSE, J.L. BOSSART and J.M. SCRIBER. 1991. Papilio canadensis and P. glaucus (Papilionidae) are distinct species. J. of the Lepidopterists' Soc. 45:245-258.

13. HILCHIE, G.J. 1985. The tiger beetles of Alberta (Coleoptera: Carabidae,Cicindelini). Quaestiones Entomologicae 21:319-347.

14. HOWE, W.H. (ed.). 1975. The butterflies of North America. Doubleday and Co. Inc. New York. 632 pp.

15. KONDLA, N.G. 1985. Skippers and butterflies of a boreal forest sand dune area in Alberta. Alberta Naturalist 15:42-48.

16. - 1986. Skippers and butterflies of the Kootenay Plains, Alberta. Alberta Naturalist 16:11-14.

17. — 1991. A discussion on the correct status of Colias eurytheme alberta. Utahensis 6:44-45.

18. - 1992. An update on the butterflies of the Redwater sand dunes. Alberta Naturalist 22:10-17.

19. KONDLA, N.G. and C. SCHMIDT. 1991. Fall emergence of Plebejus rusticus. Alberta Naturalist 21:50.

20. LARSON, D.J. 1975. The predaceous water beetles (Coleoptera: Carabidae, Cicindelini). Quaestiones Entomologicae 21:319-347.
21. LLEWELLYN-JONES, J.R.J. 1951. An annotated check list of the macrolepidoptera of British Columbia. Ent. Soc. of British Columbia, Occasional Paper No. $1.148 \mathrm{pp}$.

22. MACNEIL, C.D. 1964. The skippers of the genus Hesperia in western North America with special reference to California (Lepidoptera:Hesperiidae). University of California Publications in Entomology 35:1-222.

23. MILLER, J.Y. 1992. The common names of North American butterflies. Smithsonian Institution Press, Washington. $177 \mathrm{pp}$.

24. MILLER, L.D. and F.M. BROWN 1981. A catalogue/checklist of the butterflies of America North of Mexico. The Lepidopterists' Society Memoir No. 2. $280 \mathrm{pp}$.

25. MOSS, E.H. 1952. Grassland of the Peace River region, western Canada. Can. J. of Botany 30:98-124.

26. - 1953. Forest communities in northwestern Alberta. Can. J. of Botany $31: 212-252$.

27. REIST, J.D. 1979. Callophrys niphon (Lycaenidae) in Alberta with notes on the identification of $C$. niphon and $C$. eryphon. J. of the Lepidopterists' Soc. 33:248-253.

28. SCOTT, J.A. 1979. The identity of the Rocky Mountain Lycaena dorcas-helloides complex. J. of Research on the Lepidoptera 17:40-50.

29. _ 1986. The butterflies of North America: a natural history and field guide. Stanford University Press, Stanford. $583 \mathrm{pp}$.

30. - 1992. Hostplant records for butterflies and skippers (mostly from Colorado) 1959-1991, with new life histories and notes on oviposition, immatures and ecology. Papilio (New Series) 6:1-171.

31. SHEPARD, J.H. 1981. (compiler) Zone 2: Pacific Northwest: Oregon, Washington, British Columbia. p. 15 in 1980 Season Summary, News of the Lepidopterists' Soc. 1981(2):13-28.

32. — 1982. (compiler) Zone 2: Pacific Northwest: Oregon, Washington, British Columbia. p.16 in 1981 Season Summary, News of the Lepidopterists Soc. 1982(2):13-31. 
33. - 1983. (compiler) Zone 2 Pacific Northwest: Oregon, Washington, British Columbia. pp.15-16 in 1982 Season Summary, News of the Lepidopterists' Soc. 1983(2):13-35.

34. - 1984. (compiler) Zone 2 Pacific Northwest: Idaho, Oregon, Washington, British Columbia. pp. 14-15 in 1983 Season Summary, News of the Lepidopterists' Soc. 1984(2):13-33.

35. - 1990. (compiler) Zone 2 Pacific Northwest: Idaho, Oregon, Washington, British Columbia. pp. 14-15 in 1989 Season Summary, News of the Lepidopterists' Soc. 1990(2): 13-34.

36. SOPER, J.D. 1948. Mammal notes from the Grande Prairie-Peace River region, Alberta. J. of Mammalogy 29:49-64.

37. - 1949. Birds observed in the Grande Prairie-Peace River region of northwestern Alberta, Canada. Auk 66:233-257.

38. SPALDING D.A.E. (senior editor) 1980. A nature guide to Alberta. Provincial Museum of Alberta Special Publication No. 5. Hurtig. 368 pp.

39. SPERLING, F.A.H. 1987. Evolution of the Papilio machaon species group in
Western Canada. Quaestiones Entomologicae 23:198-315.

40. SPERLING, F.A.H. and N.G. KONDLA. 1991. Alberta Swallowtails and Parnassians: natural history, keys and distribution. Blue Jay 49:183-192.

41. STANFORD, R.E. 1980. (compiler) Zone 3 (Rocky Mountains): Alberta, Montana, Wyoming, Utah, Colorado and New Mexico. p. 15 in 1979 Season Summary, News of the Lepidopterists' Soc. 1980(2):13-27.

42. - 1982. (compiler) Zone 3: Rocky Mountains: Alberta, Idaho, Montana, Wyoming, Utah, Colorado, and New Mexico. p. 17 in 1981 Season Summary, News of the Lepidopterists' Soc. 1982(2):13-31.

43. ___ 1983. (compiler) Zone 3. Rocky Mountains: Alberta, Idaho, Montana, Utah, Colorado and New Mexico. $p$ 16-17 in 1982 Season Summary, News of the Lepidopterists' Soc. 1983(2):13-35.

44. - 1992. (compiler) Zone 4. Rocky Mountains: Alberta, Montana, Wyoming, Utah, Colorado and New Mexico. p 6-13 in 1991 Season Summary, News of the Lepidopterists' Soc. 1992(2):1-31. 


\section{Table 1. LIST OF SPECIFIC COLLECTING SITES \\ WITH REFERENCE NUMBERS SHOWN ON FIGURE 1}

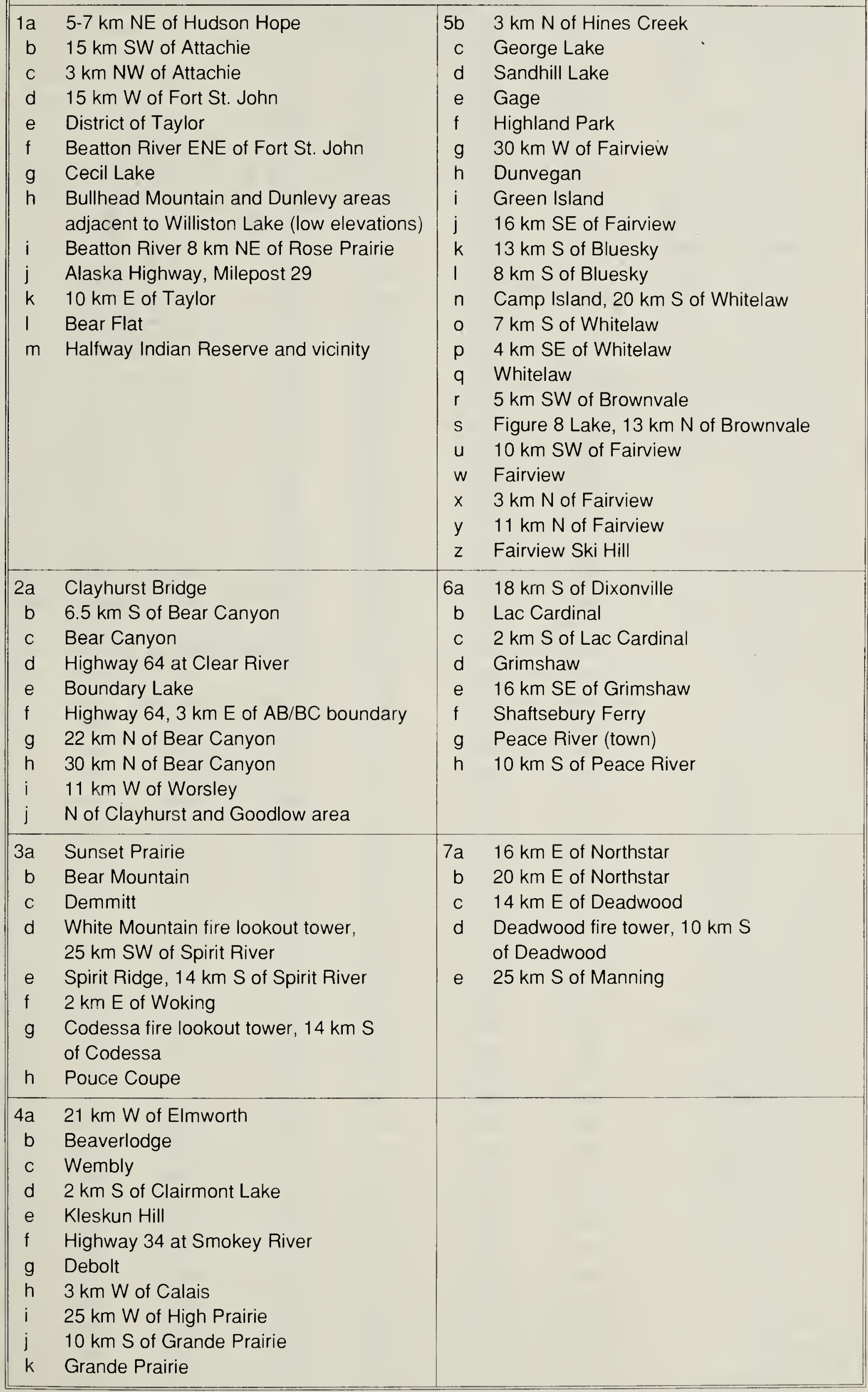




\begin{tabular}{|c|c|c|c|c|c|c|}
\hline \multicolumn{7}{|c|}{$\begin{array}{l}\text { ' } X \text { ' = species has been found in a phenology unit, ' } O \text { ' }=\text { it has not. Each month is } \\
\text { divided into } 3 \text { phenology units; the first days } 1-10 \text {, the second days } 11-20 \text { and the } \\
\text { third days } 21 \text {-end. }\end{array}$} \\
\hline SPECIES & APR & MAY & JUN & JUL & $A \cup G$ & SEP \\
\hline Thorybes pylades & 000 & oXX & $X X X$ & oXo & 000 & 000 \\
\hline Erynnis icelus & 000 & $X X X$ & $X X X$ & 000 & 000 & Oo० \\
\hline Erynnis persius & 000 & $o X X$ & $X X X$ & 000 & 000 & 000 \\
\hline Pyrgus centaureae & 000 & 000 & Xoo & 000 & 000 & 000 \\
\hline Pyrgus communis & 000 & oXo & $X X X$ & oXo & $X X X$ & ooo \\
\hline Carterocephalus palaemon & 000 & $o X X$ & $X X X$ & Xoo & ooo & ooo \\
\hline Oarisma garita & 000 & ooX & $X X X$ & Xoo & 000 & 000 \\
\hline Hesperia assiniboia & 000 & 000 & 000 & 000 & $X X X$ & 000 \\
\hline Polites mystic & 000 & 000 & oXX & $X X X$ & oXo & 000 \\
\hline Amblyscirtes vialis & 000 & $o X X$ & $X X X$ & 000 & 000 & O০o \\
\hline Papilio machaon & 000 & ooX & $X X X$ & XXo & 000 & 000 \\
\hline Papilio zelicaon & 000 & $o X X$ & XoX & Xoo & 000 & 000 \\
\hline Papilio canadensis & 000 & oXX & $X X X$ & XXo & 000 & Ooo \\
\hline Pieris occidentalis & XoX & $X X X$ & $X X X$ & $X X X$ & $X X X$ & Xoo \\
\hline Pieris napi & 000 & $X X X$ & XXo & ooX & O०० & 000 \\
\hline Pieris rapae & ooX & $X X X$ & $X X X$ & $X X X$ & $X X X$ & Xoo \\
\hline Euchloe ausonides & 000 & oXX & $X X X$ & 000 & Xoo & 000 \\
\hline Euchloe creusa & o०० & ooo & ooX & OOO & OOO & 000 \\
\hline Colias philodice & 000 & $X X X$ & $X X X$ & $X X X$ & $X X X$ & Xox \\
\hline Colias christina & 000 & 000 & ooX & XoX & XXo & ০oo \\
\hline Colias canadensis & 000 & ooX & ০০০ & Xoo & 000 & ooo \\
\hline Colias gigantea & 000 & 000 & $O X X$ & Xoo & 000 & 000 \\
\hline Colias interior & 000 & 000 & ooX & XoX & Xoo & 000 \\
\hline Colias palaeno & 000 & ০০০ & oXo & ০o० & 000 & ০o० \\
\hline Lycaena hyllus & 000 & 000 & O০o & 000 & oXo & 000 \\
\hline Lycaena helloides & 000 & 000 & ooX & 000 & $O X X$ & 000 \\
\hline Lycaena dorcas & 000 & 000 & 000 & Xoo & Xoo & 000 \\
\hline Lycaena mariposa & ००० & 000 & ooX & ooX & Xoo & 000 \\
\hline Harkenclenus titus & 000 & 000 & ooX & $X X X$ & Xoo & 000 \\
\hline Satyrium liparops & ००० & OOO & ooX & $X X X$ & 000 & 000 \\
\hline Callophrys augustinus & 000 & $X X X$ & oXo & 000 & 000 & 000 \\
\hline Callophrys polios & ooX & $X X X$ & Xoo & ০o० & 000 & 000 \\
\hline Callophrys niphon & 000 & OXX & 000 & ০o० & 000 & 000 \\
\hline Callophrys eryphon & 000 & XXo & oXo & 000 & 000 & 000 \\
\hline Everes amyntula & 000 & $X X X$ & $X X X$ & XXo & Xoo & 000 \\
\hline Celastrina argiolus & XoX & $X X X$ & XXo & Xoo & 000 & 000 \\
\hline Glaucopsyche lygdamus & ooX & $X X X$ & $X X X$ & Xoo & 000 & 000 \\
\hline Plebejus idas & ০০o & ০০০ & ooX & XXo & $X X_{0}$ & ০o० \\
\hline Plebejus saepiolus & 000 & ooX & $X X X$ & $X X X$ & 000 & 000 \\
\hline Plebejus rusticus & 000 & $X X X$ & $X X X$ & oXo & 000 & 000 \\
\hline Spejeria cybele & o०o & 000 & ooX & XXo & $X X X$ & 000 \\
\hline Speyeria aphrodite & 000 & 000 & ০o० & $X X X$ & $X X X$ & Xoo \\
\hline Speyeria hollandi & ০০০ & ০o० & ooX & 000 & $X X_{0}$ & 000 \\
\hline Speyeria electa & ০oo & 000 & $X X X$ & $X X X$ & Xoo & ००० \\
\hline Speyeria mormonia & ০o० & 000 & 000 & ooo & ooX & O०० \\
\hline Boloria eunomia & 000 & 000 & $X X X$ & ooo & 000 & 000 \\
\hline Boloria selene & 000 & oXo & $X X X$ & $X X X$ & 000 & 000 \\
\hline Boloria bellona & ০০০ & $X X X$ & $X X X$ & Xoo & $X X X$ & 000 \\
\hline Boloria frigga & 000 & oXX & $X X X$ & 000 & 000 & 000 \\
\hline Boloria freija & ooX & $X X X$ & XXo & 000 & 000 & O०० \\
\hline Boloria titania & 000 & 000 & 000 & ooX & $X X X$ & 000 \\
\hline
\end{tabular}




\begin{tabular}{|c|c|c|c|c|c|c|}
\hline Table 2 (continued) & ULT B & TERFL & LIGH7 & IENC & & \\
\hline SPECIES & APR & MAY & JUN & JUL & $A \cup G$ & SEP \\
\hline Chlosyne gorgone & 000 & oxX & $X X X$ & 000 & 000 & 000 \\
\hline Chlosyne palla & 000 & ooX & $X X X$ & $x X_{0}$ & 000 & 000 \\
\hline Phyciodes morpheus & 000 & ooX & $X X X$ & XXo & $X X_{0}$ & 000 \\
\hline Phyciodes batesii & 000 & ooX & $X X X$ & $x X_{0}$ & 000 & o०o \\
\hline Phyciodes pratensis & 000 & 000 & ooX & 000 & 000 & 000 \\
\hline Polygonia satyrus & oXX & $X X X$ & ooX & oXX & $X X X$ & 000 \\
\hline Polygonia faunus & oXX & oXX & Xoo & 000 & $X X X$ & 000 \\
\hline Polygonia gracilis & ooX & oXX & $x_{0}$ & 000 & o०० & 000 \\
\hline Polygonia progne & $o x X$ & $x X X$ & $X X X$ & 000 & $X X X$ & ০০o \\
\hline Nymphalis vau-album & 000 & ooX & ooX & ooo & $X X_{0}$ & $\infty 00$ \\
\hline Nymphalis antiopa & ooX & $X X X$ & $X X X$ & 000 & $X X X$ & 000 \\
\hline Nymphalis milberti & 000 & $X X X$ & oXX & oXo & $X X_{0}$ & 000 \\
\hline Vanessa cardui & 000 & ooX & $x X_{0}$ & 000 & Xoo & Xoo \\
\hline Vanessa atalanta & 000 & 000 & XXo & 000 & ০o० & ০০০ \\
\hline Limenitis arthemis & 000 & 000 & $x X X$ & $X X_{0}$ & $x x_{0}$ & 000 \\
\hline Coenonympha inornata & 000 & oXX & $X X X$ & $X X_{0}$ & 000 & 000 \\
\hline Cercyonis pegala & 000 & 000 & $00 X$ & $X X X$ & $X X X$ & 000 \\
\hline Cercyonis oetus & 000 & 000 & 000 & $X X X$ & $X X_{0}$ & 000 \\
\hline Erebia disa & 000 & 000 & Xoo & 000 & o०o & o०० \\
\hline Erebia discoidalis & oox & $x X x$ & ০০o & 000 & ooo & ০o० \\
\hline Erebia epipsodea & 000 & oXX & $x x x$ & 000 & ००० & o०o \\
\hline Oeneis macounii & 000 & 000 & OXo & 000 & 000 & 000 \\
\hline Oeneis uhleri & 000 & $X X X$ & $X X X$ & Xoo & 000 & 000 \\
\hline Oeneis alberta & $00 x$ & $x x x$ & XXo & 000 & 000 & 000 \\
\hline Oeneis jutta & 000 & 000 & $X X_{0}$ & 000 & 000 & 000 \\
\hline
\end{tabular}




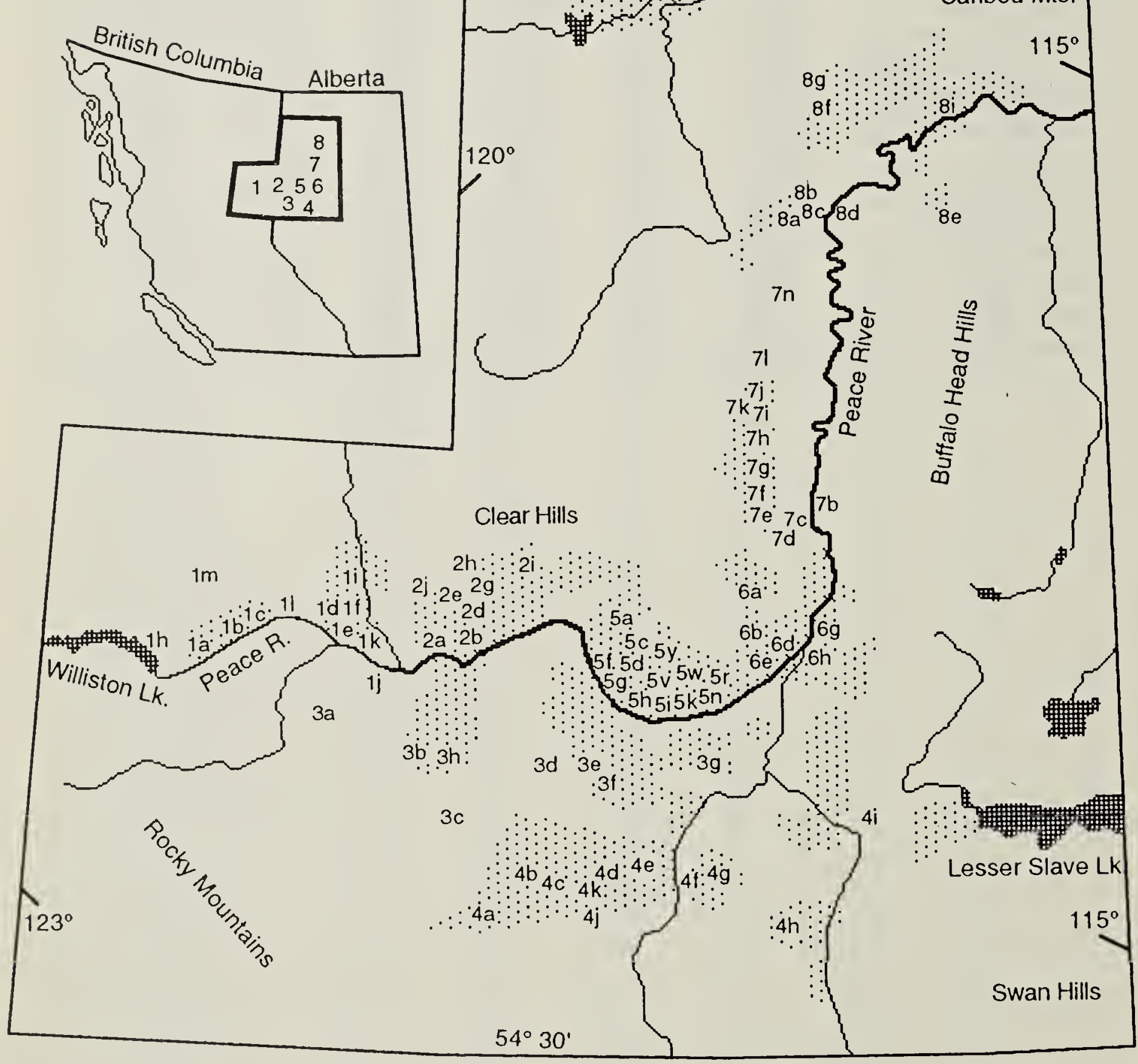

Figure 1. LOCATION OF COLLECTING SITES LISTED IN TABLE 1.

Stippled portions show areas identified as containing native grasslands. ${ }^{25}$ Insert shows study region within Alberta and British Columbia, with numbers showing eight general collecting areas. Some sites are not shown because they would overlap nearby sites in the figure; missing sites can be related to nearby sites by using Table 1. 